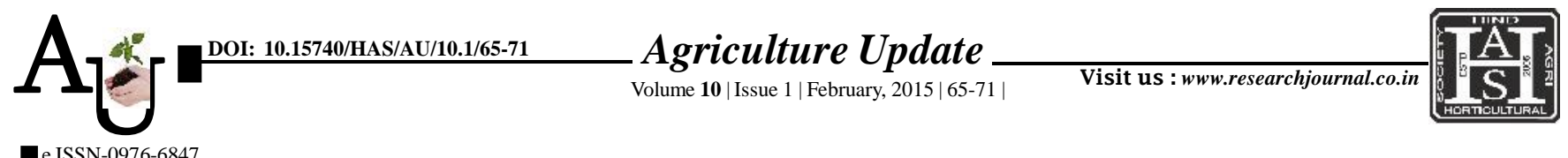
A CAsE Study: Analysis of websites of agricultural universities
in Maharashtra : A web analytic study 口 P.S. KAPSE*, P.R. DESHMUKH, J.V. EKALE AND N.M. TAMBOLI

Article Chronicle : Received : 23.07.2014;

Accepted :

26.01.2015

Key Words :

Content analysis, Websites, Webometrics analysis, SAU's
SUMMARY : The present study was undertaken to examine the content of SAU's websites in Maharashtra and compare with each other on the basis of ICAR guidelines and to appraise webometrics of the SAUs websites. The result of the study showed that general information such as about institute, how to reach, organizational setup, regional stations, AICRPs project were available on all SAU's websites. All SAU's websites have web objects about academic programme, admission, academic rules and regulation, student welfare. The study indicated that all the websites of SAU's have web objects about ongoing projects, research achievement and varieties developed. Agro advisory and help line available on every websites of SAU's. Information about books, periodicals, journals and online/offline literature database is provided in separate internal links of library webpage of all the SAUs. Web object about tenders and photo gallery and RTI act information were mentioned on the websites of all SAU's. Webometric analysis of SAUs websites showed that website of Dr. Panjabrao Deshmukh Krishi Vidyapeeth, Akola, Dr. Balasaheb Sawant Konkan Krishi Vidyapeeth, Dapoli and Mahatma Phule Krishi Vidyapeeth, Rahuri occupies $1^{\text {st }}, 2^{\text {nd }}$ and $3^{\text {rd }}$ positions, respectively whereas Vasantrao Naik Marathwada Krishi Vidyapeeth, Parbhani holds $4^{\text {th }}$ place among the SAUs. Dr. Balasaheb Sawant Konkan Krishi Vidyapeeth, Dapoli and Dr. Panjabrao Deshmukh Krishi Vidyapeeth, Akola shares $1^{\text {st }}$ rank with 5 points out of 10 points whereas websites of Vasantrao Naik Marathwada Krishi Vidyapeeth, ranks $2^{\text {nd }}$ with 4 points out of 10 points. It is indicated that size of home page of websites of Vasantrao Naik Marathwada Krishi Vidyapeeth, Parbhani, Dr. Balasaheb Sawant Konkan Krishi Vidyapeeth, Dapoli and Dr. Panjabrao Deshmukh Krishi Vidyapeeth, Akola are $15.14 \mathrm{~kb}, 22.58 \mathrm{~kb}$ and $50.94 \mathrm{~kb}$, respectively. The study helps the webmaster and the respective university to improvise the usability of websites.

How to cite this article : Kapse, P.S., Deshmukh, P.R., Ekale, J.V. and Tamboli, N.M. (2015). Analysis of websites of agricultural universities in Maharashtra : A web analytic study. Agric. Update, 10(1): 65-71.

Author for correspondence :

\section{P.S. KAPSE}

Department of Extension

Education, College of

Agriculture, Vasantrao

Naik Marathwada Krishi

Vidyapeeth, PARBHANI

(M.S.) INDIA

E-mail : pravinkapse@

rediffmail.com

See end of the article for

authors' affiliations 